\title{
Bitlis İli Şartlarında Merkezi Isıtma Sisteminde Kullanılan Farklı Yakıt Türlerinin Ekonomik ve Çevresel Etkilerinin İncelenmesi
}

\author{
Faruk ORAL ${ }^{1 *}$, Ali ELHUVEYDİ ${ }^{2}$ \\ ${ }^{1}$ Bitlis Eren Üniversitesi, Mühendislik Mimarlık Fakültesi, Makine Müh. Bölümü, Bitlis \\ ${ }^{2}$ Makine Mühendisi, Rasus Chemistry Cleaning and Cosmetics, Küsget Sanayi Sitesi, Gaziantep \\ (ORCID: 0000-0003-0607-3350) (ORCID: 0000-0002-4114-0785)
}

\begin{abstract}
$\ddot{O} \mathbf{z}$
Günümüzde artan enerji maliyetleri ve binaların 1sıtılması sonucu ortaya çıkan zararlı gaz emisyonları, binalarda enerjinin verimli, tasarruflu ve çevresel kirliliği azaltacak biçimde kullanılmasını gerektirmektedir. Bu çalışmada, Bitlis il merkezinin de içerisinde bulunduğu Rahva yerleşkesinde kurulmuş bulunan Bitlis Eren Üniversitesi personel lojmanlarından bir binanın 1sıtılmasında kullanılan farklı yakıt türlerinin enerji tasarrufu, ssıtma maliyeti ve oluşan karbondioksit emisyonları incelenmiştir. İzolasyon olarak, binada mevcut olan izolasyonda dahil edilerek toplamda üç farklı izolasyon tipi seçilmiştir. Isı kaybının ve 1sıtma enerjisi ihtiyacının belirlenmesinde, TS 825 'te belirtilen standartları kapsayan 1sı yalıtım programı kullanılmıştır. Yapılan hesaplamalar sonucunda; hâlihazır binada 1sıtma sezonları için kullanılan yakıtlar dikkate alındığında hem teorik hem de gerçek yakıt tüketim maliyeti ile $\mathrm{CO}_{2}$ emisyonunun en düşük değeri doğalgaz yakıtında meydana geldiği tespit edilmiştir. $\mathrm{Bu}$ binada fueloil yakıtı yerine doğalgaz kullanılması durumunda yakıt tüketim maliyeti oranlarının teorik olarak \%46 gerçekte ise \%64 düş̧üğ̈̈ ve $\mathrm{CO}_{2}$ emisyonu oranlarının ise teorik olarak \%63, gerçekte ise \%61 düştügü tespit edilmiştir. Sonuçta; binada 1Sı yalıtımı kullanımının ısı kayıplarını dolaysıyla gerekli ısı ihtiyacını önemli oranda azalttığı, gerçek yakıt tüketiminin teorik yakıt tüketiminden fazla olduğu, en düşük maliyetli, en tasarruflu ve en çevre dostu yakıtın doğalgaz yakıtı olduğu tespit edilmiştir.
\end{abstract}

Anahtar kelimeler: Merkezi 1sıtma sistemi, yakıt tüketimi, maliyet analizi, enerji tasarrufu.

\section{Investigation of Economic Effects of Different Fuel Types Used in Central Heating System in Bitlis Province Conditions}

\begin{abstract}
Today, increasing energy costs and harmful gas emissions resulting from the heating of buildings require the use of energy in buildings in an efficient, economical and environmentally friendly manner. In this study, energy savings, heating costs and carbon dioxide emissions of different fuel types used in the heating of a building from Bitlis Eren University staff lodgings, located in Rahva campus where Bitlis city center is located, were examined. As insulation, three different insulation types have been selected, including the existing insulation in the building. In determining the heat loss and heating energy need, a thermal insulation program covering the standards specified in TS 825 (Turkish Standards) was used. As a result of the experiments made, considering the fuels used in the current building for heating seasons, it has been determined that the lowest value of $\mathrm{CO}_{2}$ emission occurs in natural gas fuel, with both theoretical and actual fuel consumption costs. It has been demonstrated that if natural gas is used instead of fuel oil in this building, the fuel consumption cost rates drop by $46 \%$ theoretically and $64 \%$ actually, and the $\mathrm{CO}_{2}$ emission rates decrease by $63 \%$ theoretically and $61 \%$ actually. After all; it has been determined that the use of thermal insulation in the building significantly reduces the heat losses and therefore the required energy for heating, the actual fuel consumption is higher than the theoretical fuel consumption, the lowest cost, the most economical and the most environmentally friendly fuel is natural gas.
\end{abstract}

Keywords: Central heating system, fuel consumption, cost analysis, energy saving.

*Sorumlu yazar: foral@beu.edu.tr

Geliş Tarihi: 05.10.2020, Kabul Tarihi: 11.01.2021 


\section{Giriş}

Enerji, yeryüzünde yaşamın vazgeçilmez bir unsuru olup teknolojinin gelişmesinde ve ilerlemesinde en önemli kaynaklardan biridir. Tüm dünyada enerjiye olan ihtiyacın gittikçe artması ve kullanımında artan çevre sağlığı problemleri, enerjinin etkin ve verimli kullanımını önemli hale getirmiştir. Fosil enerji kaynakları bakımından dışa bağımlı olan Türkiye'de son yıllarda giderek artan enerji talebi karşısında enerjinin verimli kullanımına ilişkin çalışmaları zorunlu hale getirmiştir. Türkiye'nin iç ve doğu bölgelerinde kış ayları oldukça soğuk geçmesi binaların 1sıtılması için harcanan enerji miktarını artırmaktadır.

Yapılan araştırmalar, binalarda tüketilen enerjinin yaklaşık olarak \%82'sinin 1sıtma amacıyla kullanıldığını göstermektedir. Binalarda ve ısıtma sistemlerinde uygulanacak çeşitli teknikler ile önemli oranda enerji tasarrufunun sağlanması mümkündür. $\mathrm{Bu}$ nedenle konutlarda kullanılan 1sıtma sistemlerinin tasarımı, kullanılacak yakıtın türü ve maliyetleri, enerjinin verimli kullanılması açısından son derece önemlidir $[1,2]$.

Binalarda enerji tasarrufu bakımından yapılan uygulamaların en başında 1sı yalıtımı gelmektedir. Binalarda kış aylarında 1sı kayıplarını yaz aylarında ise 1sı kazançlarını azaltmak için en etkili yol ısı yalıtımıdır. Bilindiği gibi yalıtımın kalınlığının artması ısı kazanç ve kayıpları önemli ölçüde azaltırken yalıtım maliyetinde de artışa neden olmaktadır. İkinci aşamada ise, 1sıtma maliyetini düşürmek, baca gazı emisyonunu azaltarak çevre sağlığı konusunda yaşanacak olumsuzlukları azaltmak için kullanılacak en uygun yakıt türünü ve isıtma sistemini belirlemektir. Soğuk iklim bölgelerinde binaların 1sıtılmasında daha fazla 1sı enerjisi ihtiyacı oluşacağından bu durum yakıt tüketimi ile beraber baca gazı emisyonlarında artışa neden olmaktadır. Bunun sonucunda 1sıtma maliyetlerinin artmasına, daha fazla zararlı gazların çevreye atılmasına neden olmaktadır. Baca gazı emisyonlarından karbondioksit $\left(\mathrm{CO}_{2}\right)$ ve kötü yanma sonucu oluşan karbon monoksit $(\mathrm{CO})$ çevre ve insan sağlığını olumsuz biçimde etkileyen gazlardır. $\mathrm{Bu}$ nedenle binaların 1sıtılasında enerjiyi etkin ve verimli kullanmak çok önem arz etmektedir. Yakıtların yanması sonucu oluşan $\mathrm{CO}_{2}$ emisyonu bu çalışmada temel parametre olarak kullanılmıştır.

Türkiye'de, Enerji Bakanlığının yaptığı araştırmaya göre, bina sektöründe \%30, sanayi sektöründe $\% 20$ ve ulaşım sektöründe $\% 15$ olmak üzere önemli düzeyde enerji tasarruf potansiyeli olduğu tespit edilmiştir [3]. Ülkemizde bina sektöründe görülen tasarruf potansiyeli enerjinin etkin ve verimli kullanılmasının önemini vurgulamaktadır.

Isı yalıtımı, enerji tasarrufu ve enerji verimliliği ile ilgili literatürde yapılmış olan birçok çalışma bulunmaktadır. Konu ile ilgili Gürel ve Daşdemir [4], yaptıkları çalışmada Türkiye'nin farklı iklim bölgelerinden seçilen Aydın, Edirne, Malatya ve Sivas illerinin ısıtma ve soğutma yüklerine göre optimum yalıtım kalınlığı, enerji tasarrufu ile geri ödeme süresini incelemişlerdir. Yalıtım kalınlığg ile enerji tasarrufu en fazla Sivas en düşük Aydın ilinde, geri ödeme süresinin en büyük değeri Aydın en küçük değeri ise Sivas ilinde gerçekleştiğini belirlemişlerdir. Yılmaz [5], çalışmasında 3. ve 4. iklim bölgelerinde bulunan Konya ve Erzincan illerinden 10 farklı apartmanın 1sı yalıtım analizini yapmıştır. Seçilen binaların 1sı yalıtımı yapıldıktan sonra tasarruf oranının \%62 civarı olduğu sonucuna varmıştır. Oğuz ve Kırmacı [6], çalışmalarında Bartın İlinde kullanılan kömürlü merkezi, fueloil merkezi, doğal gazlı bireysel ve doğal gazlı merkezi olmak üzere 4 farklı 1sıtma sisteminin ekonomik ve çevresel etkilerini incelemişlerdir. İlgili çalışmada 4 farklı bina modelini kullanarak ısı kayıpları hesaplanmıştır. Yaptıkları çalışmada en çevreci ve en ekonomik 1sıtma sisteminin doğal gazlı merkezi 1sıtma sistemi olduğu sonucuna varmışlardır. Kaya ve ark. [7], Erzincan ilindeki binalarda 1s1 yalıtımının enerji tasarrufuna etkisini incelemişlerdir. Yalıtımsız binalarda 4, 5 ve $8 \mathrm{~cm}$ kalınlıklarında yalıtımın olması durumunda, enerji tasarrufunun verilen değerlere göre sirasıyla, \%56.20, \%58.51 ve \%61.19 değerinde gerçekleştiğini hesaplamışlardır. Canpolat ve ark. [8], yaptıkları çalışmada iki farklı iklimsel bölgede bulunan Bursa ve Bayburt illeri için, 1sıtma, soğutma ve yıllık enerji ihtiyaçlarına göre güneş radyasyonu etkisini göz önüne alarak optimum yalıtım kalınlığını hesaplamışlardır. Bayburt ilinin optimum kalınlığı daha fazla, yatırımın geri ödeme süresinin daha kısa olduğu sonucuna ulaşmışlardır. Rüşen ve ark. [2], tarafindan yapılan çalışmada Karamanoğlu Mehmetbey Üniversitesinin enerji açısından mevcut durumu ve enerji verimlilik potansiyeli incelemiş 2016 y1lı için \%18'e varan enerji tasarruf potansiyelinin olduğu tespit edilmiştir.

Bitlis ili 4.derece iklim bölgesinde bulunmaktadır. İlde karasal iklim hüküm sürmekte olup kış aylarının uzun ve soğuk geçmesi nedeniyle binaların 1sıtılması amacıyla tüketilen enerji fazla 
olmaktadır. Dolayısıyla burada binaların ssitılması yüksek maliyet gerektirmektedir. $\mathrm{Bu}$ nedenle, binaların yıllık 1sıtma ihtiyaçlarının maliyet analizinin yapılması önemlidir. Bitlis il merkezi yerleşiminin, Bitlis Eren Üniversitesi Kampüs yerleşkesinin de bulunduğu Rahva bölgesine doğru kayması ve bu bölgenin İlin en soğuk yerlerinden biri olması nedeniyle bölge bu çalışma için inceleme sahası olarak seçilmiştir.

$\mathrm{Bu}$ çalışmanın amacı; bu güne kadar binaların 1sıtılmasında kullanılan yakıtların verimliliği konusunda henüz daha araştırılmayan Bitlis ilinin ısıtma sistemlerinde kullanılan farklı yakıt türlerinin ekonomisini belirlemektir. Bu amaca yönelik olarak Bitlis ili Rahva yerleşkesinde kurulan Bitlis Eren Üniversitesi kampüs alanında bulunan bir binanın ısıtma maliyeti ve enerji verimliliği incelenmiştir.

\section{Materyal ve Metot}

TS 825 "Binalarda Isı Yalıtım Kuralları" standardına göre Türkiye 5 sıcaklık bölgesine ayrılmıştır. Bitlis ili, soğuk bölgelerden biri olan dördüncü bölgede yer almaktadır. Isıtma maliyeti ve enerji verimliliğinin belirlenmesi amacı ile Bitlis-Rahva yerleşkesinde kurulu buluna Bitlis Eren Üniversitesi'ne ait personel lojmanlarından R3 blok numaralı bina seçilmiştir. Bu bina, 22 daireden müteşekkil, bir bodrum, 1 zemin ve 4 normal kattan oluşmaktadır. Binanın toplam ssıtılan alanı $3477 \mathrm{~m}^{2}$ ve brüt hacmi $10866 \mathrm{~m}^{3}$ tür.

2017-2019 y1lları arasında belirtilen binanın 1sı kaybı ve yıllık 1sıtma enerjisi ihtiyacı, Makina Mühendisleri Odası (MMO) tarafından geliştirilen ısı yalıtım programı kullanılarak hesaplanmışıır. $\mathrm{Bu}$ program, TS 825 'te belirtilen binaların 1sı kayı miktarının belirlenmesinde kullanılan denklem ve kurallara uymaktadır. Hesaplanan bu 1sı kayıp miktarlarına göre mevcut binanın 1sıtılması için gerekli olan teorik kömür, fueloil ve doğalgaz miktarı belirlenmiştir. Ayrıca mevcut binanın ısıtılması amacıyla kullanılan gerçek kömür, fueloil ve doğalgaz miktarları da ilgili birimden resmi olarak temin edilmiştir. Sonraki aşamada hesaplanan değerlerle gerçek değerlerin karşılaştırılması yapılmıştır. Binada kullanılan çeşitli yakıtların günümüzdeki birim fiyatları tespit edilmiş ve fiyatlara dayanarak binada farklı yıllarda kullanılan yakıtlara göre yıllık ısıtma maliyeti belirlenmiştir.

Isıtılacak mahallerde enerji harcamalarını azaltmanın önemli bir yolu da 1sıtma sistemi için uygun işletme yönetiminin seçimidir [9]. Bununla ilgili olarak, 1sıtma sistemi işletilirken çalışma aralığına göre genellikle 3 tür işletme yönetimi belirlenmiştir. Birincisinde, genellikle yaşamsal konutlar, hastaneler vb. yerlerin tesisatı devamlı çalışırken sadece geceleri sıcaklık azaltılır. İkinci türde, iş yerleri, okullar vb. yerlerde ısıtma sisteminin kazanına düzenli olarak günlük 10 saat çalışmaya tamamen ara verdirilir. Üçüncü türde ise, spor salonları, sergi merkezleri vb. yerlerde kullanılan kazanların 14 saat ya da daha uzun süreyle çalışması durdurulur [10]. Bu amaçla incelenen lojman binası, birinci işletme tipi temel alınarak değerlendirilmiştir.

$\mathrm{Bu}$ çalışmada incelenen binanın 1Sı kaybı miktarı, gerekli 1sı enerjisi ihtiyacı ve yanma işleminden kaynaklanan karbondioksit emisyonlarının miktarı, üç farklı durum için hesaplanmıştır. İlk durumda (I), bina duvarlarının 1sı yalıtımlı olmadığı ve pencerelerinin ise binanın mimari projesine göre kaplamasız $4 \mathrm{~mm}$ çift cam ve ara boşluk $12 \mathrm{~mm}$, 1sı geçirgenlik katsayısı $2.9\left(\mathrm{~W} / \mathrm{m}^{2} \mathrm{~K}\right)$ oldukları durumlar için 1sı enerjisi hesaplamaları yapılmıştır. Gerçek durum olan ikinci durumda (II), incelenen binanın mimari projelerinde gösterilen yalıtım malzemelerine göre hesaplamaları yapılmıştır. Seçilen binanın duvarlarda, 1S1 iletim katsayısı $0.035(\mathrm{~W} / \mathrm{mK})$ ve kalınlığ $5 \mathrm{~cm}$ olan XPS yalıtım malzemesi kullanılmıştır. Pencerelerde, birinci durumla aynı olan malzeme kullanılmıştır. Üçüncü durumda ise (III), TS825 standardında tavsiye edilen, pencere $1 \mathrm{~s} 1$ geçirgenlik katsayısı $1.8\left(\mathrm{~W} / \mathrm{m}^{2} \mathrm{~K}\right.$ ) (çift camlı, kaplamalı, $12 \mathrm{~mm}$ ara boşluklu pencere) ve duvarlarda ikinci durumdaki yalıtım özellikleri kullanıldı. Sonuç olarak, bu üç durum kapsamında gerekli tüm hesaplamalar yapıldığında, binanın yıllık yakıt tüketim miktarı, tüketim maliyeti; kömür, fueloil ve doğalgaz kullanan 1sıtma sistemleri için ayrı ayrı hesaplanmıştır.

\subsection{Isı Kaybı Hesabı}

Binalarda 1sı, yüksek sıcaklık ortamından düşük sıcaklık ortama doğru geçerek 1sı kaybı meydana getirir. Binanın 1sı kaybı dış duvarlar, tavanlar, zeminler, pencereler ve kapılarda meydana gelmektedir. Isıtılmış ortamlar arasındaki fark $4{ }^{\circ}$ C'yi geçmiyorsa, bina bir bütün olarak ele alınır ve her ortamın sıcaklığı aynı kabul edilerek 1sı kaybı hesabı yapılabilir. Binanın toplam 1sı kaybı, iletim ve taşınım 
yoluyla gerçekleşen 1sı kaybı ve havalandırma yoluyla gerçekleşen 1sı kaybının toplanması ile bulunur [11].

$$
H=H_{t}-H_{v}
$$

Bu eşitlikte yer alan $H$, bir hacmin toplam 1sı kaybını; $H_{t}$, yapı bileşeninden olan artırımlı 1sı kaybını; $H_{v}$, hava sızıntıs1 1s1 kaybını ifade etmektedir.

\subsection{Yıllık Isıtma Enerjisi ve Yakıt Tüketimi Hesabı}

Bir mahallin y1llık ihtiyacı olan 1sıtma enerjisi; aylık net 1sı ihtiyaçlarının toplanması sonucu bulunur. Aylık net 1sı ihtiyacı, iç ortamında belli bir konfor sıcaklığını sağlamak için gereken 1sı enerjisi olup, aylık iç ve güneş enerjisi kazançları toplamı, ortamın aylık toplam 1sı kayıplarından çıkarılarak hesaplanır. Yıllık ve aylık ısıtma enerjisi ihtiyacı aşağıdaki eşitlikler ile ifade edilebilir [11].

$$
\begin{aligned}
Q_{y l l} & =\sum Q_{a y} \\
Q_{a y} & =\left[H\left(T_{i}-T_{d}\right)-\eta_{a y}\left(\phi_{i a y}+\phi_{s a y}\right)\right] t
\end{aligned}
$$

(2) ve (3) eşitliklerinde yer alan $Q_{y l}$, yıllık ısıtma enerjisi ihtiyacını; $Q_{a y}$, aylık ısıtma enerjisi ihtiyacını; $H$, binanın iletim ve havalandırma ile kaybedilen özgül ısı kaybını; $T_{i}$, aylık ortalama iç sıcaklığını; $T_{d}$, aylık ortalama dış sıcaklığını; $\eta_{a y}$, kazançlar için aylık ortalama kullanım faktörünü; $\phi_{i a y}$, aylık ortalama iç kazançları (sabit alınabilir); $\phi_{s a y}$, aylık ortalama güneş enerjisi kazancını; $t$, zamanı, (saniye olarak bir ay $=86400 \times 30)$ ifade etmektedir.

Bir mahal için belirlenen 1sıtma enerjisi ihtiyacına göre tüketilen yıllık yakıt miktarı aşağıda verilen eşitlik ile belirlenebilir.

$$
B_{y}=Q_{y \imath l} /\left(H_{u} \eta_{k}\right)
$$

Burada $B_{y}$, yıllık tüketilen yakıt miktarı $\left(\mathrm{kg}\right.$ veya $\left.\mathrm{m}^{3}\right)$; Hu, kullanılan yakıtın alt 1 sıl değeri $(\mathrm{kJ} / \mathrm{kg}$ veya $\left.\mathrm{kJ} / \mathrm{m}^{3}\right) ; \eta_{k}$, kazanın verimi (\%) şeklinde tanımlanmaktadır. Yakıtların alt ısıl değeri ve kazan verimi Tablo 1'de verilmiştir.

Binanın yıllık yakıt tüketim maliyeti ise, tüketilen yakıt miktarına ve yakıt birimi fiyatına dayanarak, aşağıdaki eşitlik ile hesaplanabilir [6].

$$
M_{y}=B_{y} C_{f y a k}
$$

Burada $M_{y}$, yıllık yakıt giderlerini; $B_{y}$, yıllık yakıt tüketim miktarını; $C_{f y a k}$, yakıtın birim fiyatını ifade etmektedir. Bu çalışmada kullanılan yakıtların birim fiyatları 2019-2020 yılı dikkate alınarak düzenlenmiş ve Tablo 1'de gösterilmiştir.

Tablo 1. Yakıtların alt ısıl değeri, kazan verimi [10] ve yakıt birim fiyatı (KDV dâhil)

\begin{tabular}{lllll}
\hline Yakıt türü & $\begin{array}{l}\text { Yakıtın Alt Is1 } \\
\text { Değeri }\left(H_{u}\right)\end{array}$ & $\begin{array}{l}\text { Kazan Verimi } \\
\left(\eta_{k}\right) \%\end{array}$ & Birim & $\begin{array}{l}\text { Yakıt Birim Fiyatı } \\
\left(C_{\text {fyak }}\right) \text { TL/Birim }\end{array}$ \\
\hline Fueloil & $41860 \mathrm{~kJ} / \mathrm{kg}$ & $0.75-0.80$ & $\mathrm{~kg}$ & $4.3390[12]$ \\
Linyit kömür & $23020 \mathrm{~kJ} / \mathrm{kg}$ & $0.60-0.65$ & $\mathrm{~kg}$ & $1.6520[13]$ \\
Doğalgaz & $34535 \mathrm{~kJ} / \mathrm{m}^{3}$ & $0.85-0.92$ & $\mathrm{~m}^{3}$ & $1.8526[14]$ \\
\hline
\end{tabular}

\subsection{Karbondioksit Emisyonu Hesabı}

Isıtma tesisatında kullanılan yakıtların yanması sonucu açığa çıkan atık gazların $\% 85^{\prime}$ ini $\mathrm{CO}_{2}, \% 15$ 'lik kısmını ise yanma sonucu kalan diğer emisyon ürünleri oluşturmaktadır. Bu nedenle, karbondioksit emisyonlarının yüzdesi, yanma ürünleri emisyonlarının büyük çoğunluğunu temsil ettiğinden genellikle göz önünde bulundurulur. 5 Aralık 2008 tarih ve 27075 sayılı Resmî Gazetede yayınlanan Binalarda 
Enerji Performansı Yönetmeliği'nde (BEPY), binaların yıllık $\mathrm{CO}_{2}$ emisyonu sınırlandırılmış ve kullanılan enerji kaynağına (yakıt türüne) bağlı olarak, nihai enerji tüketimi sonucu açığa çıkan $\mathrm{CO}_{2}$ miktarının belirlenmesi için dönüşüm katsayıları (DK) verilmiştir. Binanın net enerji tüketimine bağlı olarak kullanılan yakıt cinsine göre yıllık $\mathrm{CO}_{2}$ emisyon miktarı aşağıda verilen denklem ile hesaplanabilmektedir [6].

$$
E M_{y}=0,27810^{-3} B_{y} H_{u} D K
$$

Bu eşitlikte yer alan $E M_{y}$, yıllık $\mathrm{CO}_{2}$ emisyon miktarı $(\mathrm{kg})$; DK, yakıt cinsine göre $\mathrm{CO}_{2}$ emisyonu dönüşüm katsayısını ifade etmektedir. Çalışmada kullanılan ve Binalarda Enerji Performansı Yönetmeliğinde yer alan yakıt türlerinin DK $\left(\mathrm{CO}_{2}\right)$ dönüşüm katsayıları Tablo 2'de verilmiştir.

Tablo 2. Yakıt türlerinin DK $\left(\mathrm{CO}_{2}\right)$ dönüşüm katsayıları [6]

\begin{tabular}{ll}
\hline Yakıt Türü & $\begin{array}{l}\mathrm{DK}\left(\mathrm{CO}_{2}\right) \text { dönüşüm katsayıs } \\
\left(\mathrm{kg} \text { eşd. } \mathrm{CO}_{2} / \mathrm{kWh}\right)\end{array}$ \\
\hline İthal Kömürü & 0.433 \\
Doğalgaz & 0.234 \\
Fueloil & 0.330 \\
\hline
\end{tabular}

\section{Bulgular ve Tartışma}

Çalışma kapsamında seçilmiş binanın izolasyon durumlarına göre özgül ısı kaybı hesaplanmış ve elde edilen değerler Tablo 3'te, binanın 1sıtılması için gerekli olan enerjisi ihtiyacı ise Tablo 4'te verilmiştir. Bu sonuçlar, 1sı yalıtım malzemelerinin kullanımı sırasında, toplam özgül 1sı kaybı ve dolayısıyla 1sıtma enerjisi ihtiyacında önemli bir azalma olduğunu göstermektedir.

Tablo 3. Bina durumuna göre toplam özgül $1 \mathrm{~s} 1$ kaybı $\left(\mathrm{W} /{ }^{\circ} \mathrm{C}\right.$

\begin{tabular}{cccc}
\hline $\begin{array}{c}\text { Binanın } \\
\text { Durumu }\end{array}$ & $\begin{array}{c}\text { İletim ve Taşınım Yoluyla } \\
\text { Gerçekleşen Isı Kaybı }\left(\mathrm{H}_{\mathrm{t}}\right)\end{array}$ & $\begin{array}{l}\text { Havalandırma Yoluyla } \\
\text { Gerçekleşen Isı Kaybı }\left(\mathrm{H}_{\mathrm{v}}\right)\end{array}$ & $\begin{array}{c}\text { Toplam Özgül } \\
\text { Isı Kaybı }(\mathrm{H})\end{array}$ \\
\hline I & 5458.81 & 2294.90 & 7753.71 \\
II & 2207.53 & 2294.90 & 4502.43 \\
III & 1745.55 & 2294.90 & 4040.45 \\
\hline
\end{tabular}

Tablo 4. Bina durumuna göre toplam 1sı enerjisi ihtiyacı (kWh)

\begin{tabular}{ccc}
\hline $\begin{array}{c}\text { Binanın } \\
\text { Durumu }\end{array}$ & $\begin{array}{c}\text { Is1 enerjisi } \\
\text { ihtiyac1 }\end{array}$ & $\begin{array}{c}\text { Daire başına 1S1 } \\
\text { enerjisi hitiyac1 }\end{array}$ \\
\hline I & 590389.56 & 26835.89 \\
II & 291507.63 & 13250.35 \\
III & 251422.38 & 11428.27 \\
\hline
\end{tabular}

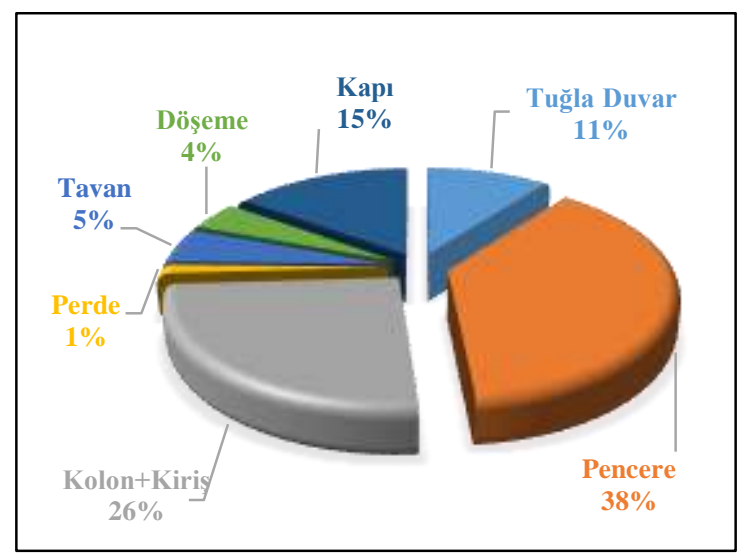

Şekil 1. Binayı oluşturan yapı bileşenlerinin özgül 1sı kaybının oransal dağılımı 
Şekil 1'de mevcut durumdaki binayı (II durumu) oluşturan yapı bileşenlerinde (pencere, tuğla duvar, kolon+kiriş, perde, tavan, döşeme ve kapı) oluşan özgül 1s1 kaybının oransal dağılımı gösterilmiştir. Şekil 1'de görüldüğü gibi bina bileşenlerinde en fazla özgül 1s1 kayb1 \%38 oranı ile pencerelerde gerçekleşmiştir. Isı kaybının pencerelerden sonra en fazla duvarlarda (tuğla duvar, kolon+kiriş ve perde) meydana geldiği tespit edilmiştir.

TS 825 standardına göre, binalardaki birim başına düşen yı1lık 1sı enerjisi ihtiyacı olan Q, yine bu standartta belirtilen derece gün bölgelerine göre olması gereken maksimum 1s1 enerjisi ihtiyacı olan Q' değerini geçmemesi gerekmektedir. Tablo 5'te, incelenen binanın birim $\left(\mathrm{m}^{3}\right)$ başına düşen yılllık 1sıtma enerjisi $(\mathrm{kWh})$ ihtiyacının sonuçları verilmiştir. Tablo 5 incelendiğinde; III durumunun birim başına düşen yıllık 1sıtma enerjisi ihtiyacı olan Q değeri, derece gün bölgesine göre olması gereken en büyük 1sıtma enerjisi ihtiyacı olan Q' değerinden daha düşüktür. Dolayısıyla binada uygulanmış olan 1sı yalıtımı hesap metoduna uygundur. Diğer durumlarda ise (I ve II) birim başına düşen yıllık 1sıtma enerjisi ihtiyacı olan Q değeri, derece gün bölgesine göre olması gereken maksimum 1sıtma enerjisi ihtiyacı olan Q' değerinin üzerindedir. Dolayısıyla binada uygulanmış olan ısı yalıtımı hesap metoduna uygun değildir.

Tablo 5. Binanın birim başına düşen yıllık ısıtma enerjisi ihtiyacı $\left(\mathrm{kWh} / \mathrm{m}^{3}\right)$

\begin{tabular}{cccc}
\hline Binanın Durumu & Q & Q $^{\prime}$ & İzolasyon Durumu \\
\hline I & 54.33 & 24.99 & Uygun Değil \\
II & 26.83 & 24.99 & Uygun Değil \\
III & 23.14 & 24.99 & Uygun \\
\hline
\end{tabular}

Isıtma enerjisi ihtiyaç değerleri hesaplandıktan sonra, kullanılan yakıt türlerine göre Eşitlik 4 kullanılarak yıllık yakıt tüketimi teorik olarak hesaplanmıştır. Elde edilen sonuçlar Tablo 6 ve Şekil 2'de verilmiştir. Bulunan bu yakıt tüketim sonuçları incelendiğinde, kömürlü merkezi 1sıtma sistemindeki yakıt tüketiminin, doğalgaz ve fueloil kullanılan merkezi ssıtma sistemindeki yakıt tüketiminden daha yüksek olduğu tespit edilmiştir.

Tablo 6. Binanın yıllık teorik yakıt tüketim miktarları

\begin{tabular}{|c|c|c|c|}
\hline $\begin{array}{l}\text { Binanın } \\
\text { Durumu }\end{array}$ & $\begin{array}{c}\text { Kullanılan } \\
\text { Yakıt }\end{array}$ & Yakıt Tüketimi & $\begin{array}{c}\text { Daire Başına Düşen } \\
\text { Tüketim }\end{array}$ \\
\hline \multirow{3}{*}{ I } & Fueloil & $63416.85 \mathrm{~kg} / \mathrm{y} 1 \mathrm{l}$ & $2882.58 \mathrm{~kg} / \mathrm{y} 1 \mathrm{l}$ \\
\hline & Kömür & $141930.33 \mathrm{~kg} / \mathrm{y} 1 \mathrm{l}$ & $6451.38 \mathrm{~kg} / \mathrm{y} 1 \mathrm{l}$ \\
\hline & Doğalgaz & $68326.93 \mathrm{~m}^{3} / \mathrm{y} 1 \mathrm{l}$ & $3105.77 \mathrm{~m}^{3} / \mathrm{y} 1 \mathrm{l}$ \\
\hline \multirow{3}{*}{ II } & Fueloil & $31312.37 \mathrm{~kg} / \mathrm{y} 1 \mathrm{l}$ & $1423.29 \mathrm{~kg} / \mathrm{y} 1 \mathrm{l}$ \\
\hline & Kömür & 70078.77 kg/yıl & $3185.40 \mathrm{~kg} / \mathrm{y} 1 \mathrm{l}$ \\
\hline & Doğalgaz & $33736.74 \mathrm{~m}^{3} / \mathrm{y} 1 \mathrm{l}$ & $1533.49 \mathrm{~m}^{3} / \mathrm{y} 1 \mathrm{l}$ \\
\hline \multirow{3}{*}{ III } & Fueloil & $27006.60 \mathrm{~kg} / \mathrm{y} 1 \mathrm{l}$ & $1227.57 \mathrm{~kg} / \mathrm{y} 1 \mathrm{l}$ \\
\hline & Kömür & $60442.23 \mathrm{~kg} / \mathrm{y} 1 \mathrm{l}$ & $2747.37 \mathrm{~kg} / \mathrm{y} 1 \mathrm{l}$ \\
\hline & Doğalgaz & $29097.60 \mathrm{~m}^{3} / \mathrm{y} 1 \mathrm{l}$ & $1322.62 \mathrm{~m}^{3} / \mathrm{y} 1 \mathrm{l}$ \\
\hline
\end{tabular}

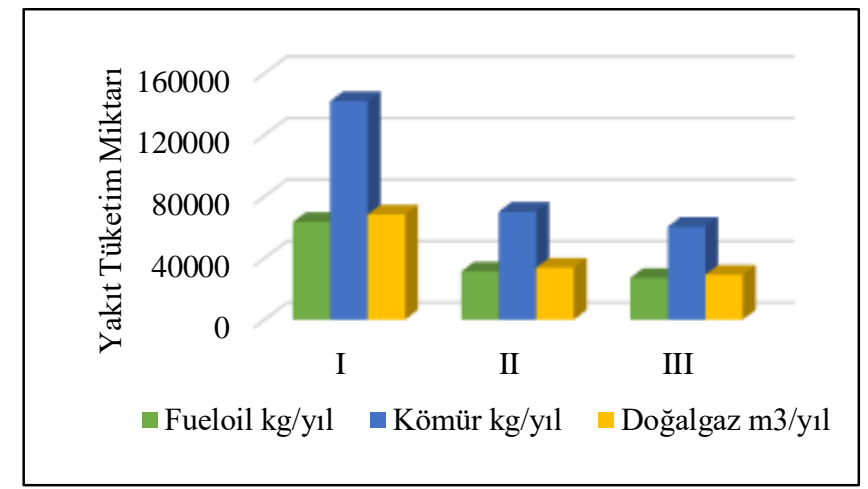

Şekil 2. Binanın yıllık teorik yakıt tüketim miktarları 
Binanın mevcut durumunda (II) 1sıtma sezonları için gerçek yıllık yakıt tüketim miktarı Bitlis Eren Üniversitesi Rektörlüğünden resmi kayıtlarından alınarak teorik sonuçlar ile birlikte Tablo 7 ve Şekil 3'de verilmiştir. Binanın merkezi 1sıtma sistemindeki teorik yıllık yakıt tüketim değerleri ile gerçek yıllık yakıt tüketim değerleri karşılaştırıldığında, gerçek tüketimin yaklaşık olarak \%21-25 oranında daha fazla olduğu görülmüştür. Gerçek tüketimdeki artışın en önemli sebeplerden biri, binanın iç 1sısının neden olduğu sıcaklık değerinin kullanıcılar için 1sıl konfor sağlayan sıcaklık değerinden (TS825'e göre $19^{\circ} \mathrm{C}$ ) daha fazla olduğu düşünülmektedir.

Tablo 7. Binanın teorik ve gerçek yıllık yakıt tüketim miktarı

\begin{tabular}{ccccc}
\hline $\begin{array}{c}\text { Isıtma } \\
\text { Sezonu }\end{array}$ & Yakıt Türü & Teorik Tüketim & Gerçek Tüketimi & $\begin{array}{c}\text { Artış Oranı } \\
(\%)\end{array}$ \\
\hline $2017-2018$ & Fueloil & $31312.37 \mathrm{~kg} / \mathrm{yll}$ & $41500 \mathrm{~kg} / \mathrm{yll}$ & 24.55 \\
- & Kömür & $70078.77 \mathrm{~kg} / \mathrm{yll}$ & Kullanılmadı & - \\
$2018-2019$ & Doğalgaz & $33736.74 \mathrm{~m}^{3} / \mathrm{yll}$ & $42862 \mathrm{~m}^{3} / \mathrm{yll}$ & 21.29 \\
\hline
\end{tabular}

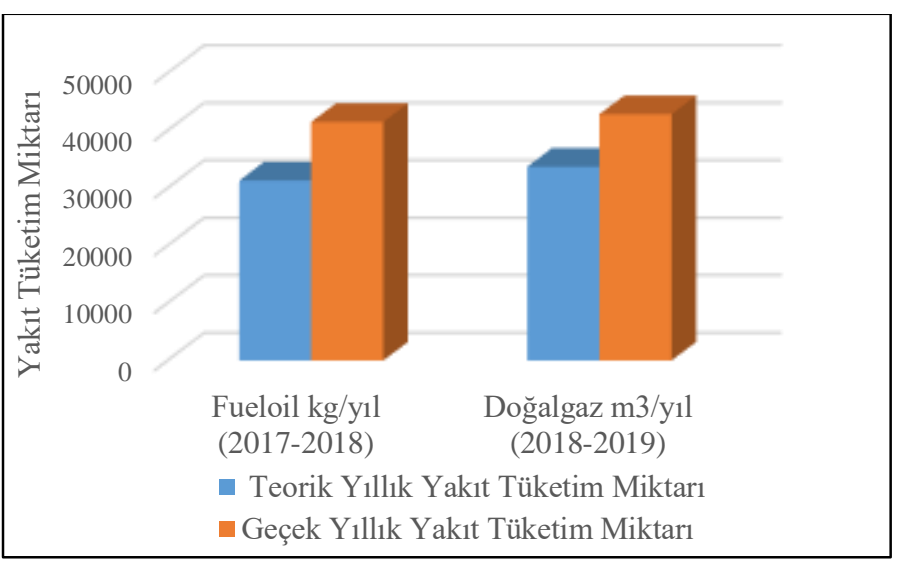

Şekil 3. Isıtma sezonları için binanın teorik ve gerçek yıllık yakıt tüketimi

Tablo 6'da elde edilen yıllık teorik yakıt tüketim değerleri, Eşitlik 5 'ten faydalanılarak yakıtların birim fiyatları ile çarpılmış ve bina durumuna göre yıllık yakıt tüketim maliyeti teorik hesaplanmıştır. Elde edilen sonuçlar Tablo 8 ve Şekil 4' de verilmiştir. Bina durumuna göre yakıt tüketimine bağlı olarak oluşan yıllık teorik $\mathrm{CO}_{2}$ emisyon miktarları ise Şekil 5'de verilmiştir.

Tablo 8. Bina durumuna göre yıllık teorik yakıt tüketimi maliyeti (TL)

\begin{tabular}{cccc}
\hline $\begin{array}{c}\text { Binanın } \\
\text { Durumu }\end{array}$ & Yakıt Türleri & $\begin{array}{c}\text { Toplam } \\
\text { Maliyeti }\end{array}$ & $\begin{array}{c}\text { Daire Başına Düşen } \\
\text { Maliyet }\end{array}$ \\
\hline \multirow{2}{*}{ I } & Fueloil & 275165.71 & 12507.53 \\
& Kömür & 234468.91 & 10657.68 \\
& Doğalgaz & 126582.47 & 5753.75 \\
\hline \multirow{2}{*}{ II } & Fueloil & 135864.37 & 6175.65 \\
& Kömür & 115770.13 & 5262.28 \\
& Doğalgaz & 62500.68 & 2840.94 \\
\hline \multirow{2}{*}{ III } & Fueloil & 117181.64 & 5326.44 \\
& Kömür & 99850.56 & 4538.66 \\
& Doğalgaz & 53906.21 & 2450.28 \\
\hline
\end{tabular}




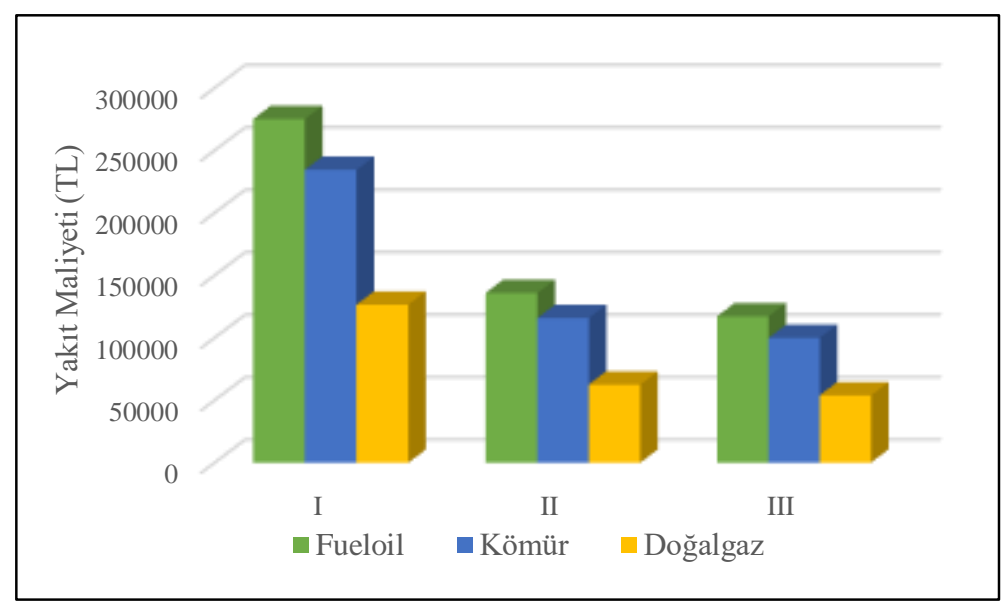

Şekil 4. Bina durumuna göre yıllık teorik yakıt tüketim maliyeti

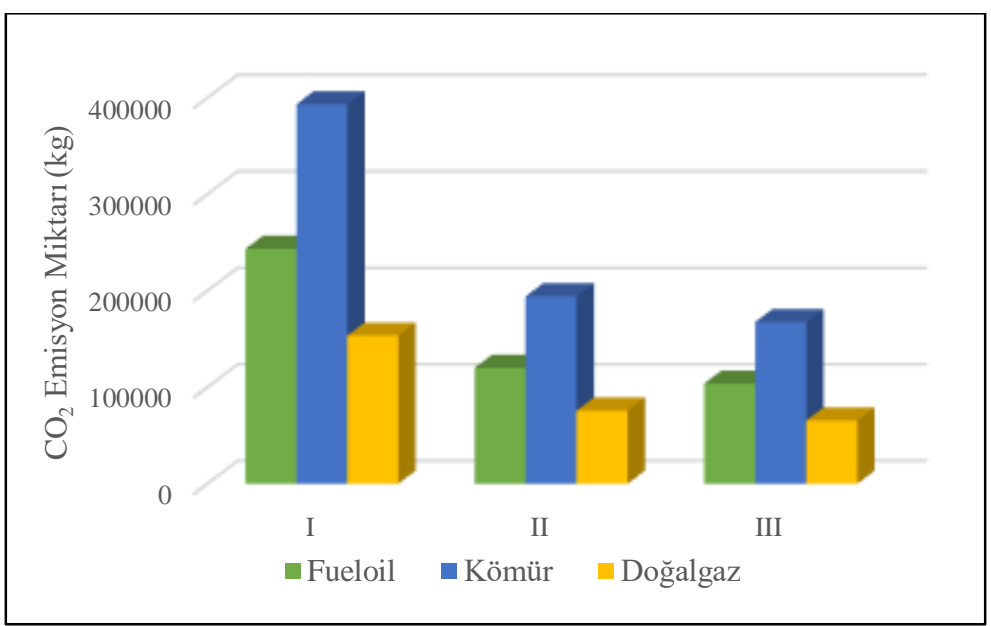

Şekil 5. Bina durumuna göre oluşan teorik $\mathrm{CO}_{2}$ emisyonu

Tablo 8, Şekil 4 ve Şekil 5 incelendiğinde; binanın ikinci durumu (duvar yalıtıml1-pencere yalıtımsız) birinci duruma göre (duvar yalıtımsız-pencere yalıtımsız), yıllık teorik yakıt tüketim maliyeti ve $\mathrm{CO}_{2}$ emisyon miktarının \%49 oranında az olduğu tespit edilmiştir. Üçünü bina durumu (duvar yalıtımlı-pencere yalıtımlı) ikinci duruma göre yıllık yakıt tüketim maliyeti ve $\mathrm{CO}_{2}$ emisyon miktarının yaklaşık \%10 oranında daha az olduğu belirlenmiştir. Ayrıca, ısıtma sisteminde kullanılan yakıt türüne bağlı olarak yapılan karşılaştırmada elde edilen sonuçlar şu şekildedir: Fueloil yakıtı yerine doğalgaz yakıtı kullanıldığında, yıllık yakıt tüketim maliyetinin \%54 oranında ve kömür yakıt yerine doğalgaz yakıtı kullanılırken ise yıllık yakıt tüketim maliyetinin $\% 46$ oranında azaldığı tespit edilmiștir. Yapılan teorik hesaplamalar sonucunda; ekonomiklik ve tasarruf noktasında maliyeti en yüksek olan fueloil ve en düşük olanın ise doğalgaz yakıtı olduğu tespit edilmiştir. Karbondioksit emisyonu açısından, fueloil yakıt yerine doğalgaz yakıtı kullanıldığında $\mathrm{CO}_{2}$ emisyon miktarının \%37 oranında ve kömür yakıt yerine doğalgaz yakıtı kullanıldığında ise $\mathrm{CO}_{2}$ emisyon miktarının \%61 oranında azaldığı tespit edilmiştir. $\mathrm{Bu}$ tespitlerden yola çıkarak teorik hesaplamalar sonucunda mevcut yakıtlar içerisinde, çevreye en zararlı yakıtın kömür, en çevre dostu yakıtın ise doğalgaz olduğu tespit edilmiştir.

Mevcut binanın (II) Tablo 7'de 1sıtma sezonları için verilen bilgiler kullanılarak Eşitlik 5 yardımı ile yakıt tüketim maliyetlerinin teorik ve gerçek değerleri Şekil 6'da verilmiştir. Yine Tablo 7'deki ısıtma sezonu için verilen mevcut değerler kullanılarak Eşitlik 6 yardımı ile yakıt tüketimi sonucu oluşan $\mathrm{CO}_{2}$ emisyonu Şekil 7'de gösterilmiştir. 


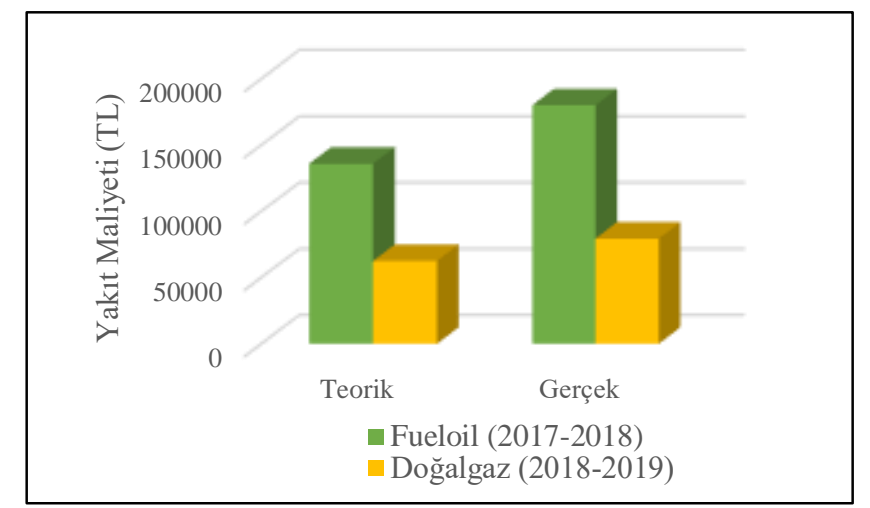

Şekil 6. Binada ısıtma sezonlarında oluşan yakıt tüketim maliyeti

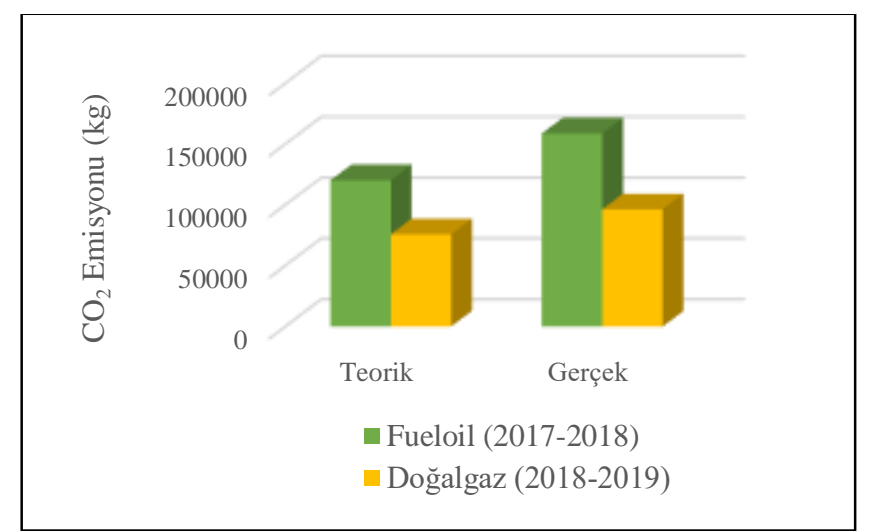

Şekil 7. Bina 1sıtma sezonlarında oluşan $\mathrm{CO}_{2}$ emisyonu

Binada verilen 1sıtma sezonları için kullanılan yakıtların tüketimi sonucu oluşan maliyetler incelendiğinde (Şekil 6); yakıtların gerçek maliyetlerin teorik maliyetlerinden daha fazla olduğu, bu fazlalık fueloil yakıtında \%25, doğalgaz yakıtında ise $\% 21$ 'lik bir artışı gösterdiği belirlenmiştir. Hem teorik hem de gerçek yakıt tüketimi maliyetlerde en düşük değer doğalgaz yakıtında meydana geldiği görülmüştür. İlgili binada fueloil yakıtı yerine doğalgaz yakıtının kullanılması durumunda, yakıt tüketim maliyetinin teorik \%46, gerçek \%44 oranında azaldığı tespit edilmiştir. Yakıt tüketimi bakımından en ekonomik yakıtın doğalgaz yakıtı olduğu görülmüştür.

Isıtma sezonları süresince verilen yakıtların tüketimi sonucu oluşan $\mathrm{CO}_{2}$ emisyonları incelendiğinde (Şekil 7); gerçek emisyon değerlerinin teorik değerlerden daha fazla olduğu görülmüştür. Doğalgaz yakıtının kullanılması durumunda teorik ve gerçek en düşük $\mathrm{CO}_{2}$ emisyonunun meydana geldiği belirlenmiştir. Binada fueloil yakıtı yerine doğalgaz yakıtının kullanılması durumunda, $\mathrm{CO}_{2}$ emisyonu miktarının teorik $\% 63$, gerçek $\% 61$ oranında düştüğü tespit edilmiştir. Bu bakımdan kullanılan yakıtlar içerisinde çevre ve insan sağlığı açısından en uygun yakıtın doğalgaz yakıtı olduğu tespit edilmiştir. Oğuz ve Kırmacı yaptıkları çalışmada [6], ikinci iklim bölgesinde bulunan Bartın ili için kömürlü, fueloil ve doğalgazlı yakıt türlerinin kullanıldığı 4 farklı ssıtma sistemi ile ilgili yaptıkları çalışmada en verimli, en ekonomik ve en çevreci 1sıtma sisteminin doğal gazlı merkezi 1sıtma sistemi olduğunu belirtmişlerdir. Bu bakımdan bu çalışma ile benzer bir sonuca ulaşmışlardır.

\section{Sonuç ve Öneriler}

Bu çalışmada kış aylarının soğuk, kar yağışlı ve uzun sürdüğü Bitlis İli Rahva yerleşkesinde kurulan Bitlis Eren Üniversitesi Kampüsü'ndeki personel lojmanlarının 1sıtılmasında kullanılan farklı yakıt türlerimin enerji verimliliği, 1sıtma maliyetleri, enerji tasarrufu ve yakit tüketimi ile oluşan $\mathrm{CO}_{2}$ emisyonları araştırılmıştır. Çalışmada elde edilen sonuçlar aşağıda verilmiştir.

- Çalışma kapsamında seçilmiş binanın izolasyon durumlarına göre yapılan isı kayıpları hesaplamaları sonucu, 1s1 yalıtım malzemelerinin kullanılmasının özgül 1s1 kaybı ve binanın 1sıtılması için gerekli 1sıtma enerjisi ihtiyacında önemli bir azalma olduğu bulunmuştur. Binanın yapı bileşenleri içerisinde en fazla 1sı kayıplarının \%38 oranında pencerelerde gerçekleştiği 
belirlenmiştir.

- Mevcut II durumunda bulunan binanın birim başına düşen yıllık ısıtma enerjisi ihtiyacının, derece gün bölgesine göre olması gereken en büyük ısıtma enerjisi ihtiyacina göre karşılaştırılmasında, binada uygulanmış olan ısı yalıtımının istenilen düzeyde olmadığı, bu binanın izolasyonunun düzenlemeye ihtiyaç duyduğu belirlenmiştir.

- Binanın teorik 1sıtma enerjisi ihtiyacı değerleri dikkate alınarak 1sıtma sisteminde kullanılan yakıt türlerine göre hesaplanan yıllık tüketimi miktarları ile gerçekte kullanılan yakıt tüketim miktarlarına göre, kömür kullanan merkezi ısıtma sistemindeki yakıt tüketimi miktarının diğer yakıt türlerine göre en yüksek değerde gerçekleştiği belirlenmiştir. Ayrıca mevcut binanın yıllık gerçek yakıt tüketim miktarlarının teorik yıllık yakıt tüketim değerlerinden yaklaşık \%11-25 oranları arasında fazla olduğu tespit edilmiştir.

- Farklı bina durumları için hesaplanan yıllık teorik yakıt tüketim maliyetlerine göre, en maliyetli yakıtın fueloil en düşük maliyetli yakıtın ise doğalgaz olduğu bulunmuştur. Yıllık yakıt tüketim maliyeti ve oluşan $\mathrm{CO}_{2}$ emisyon değerlerine göre en düşük oran üçüncü durumdaki binada gerçekleştiği görülmüştür. Yakıt türüne bağlı olarak, fueloil yakıtı yerine doğalgaz yakıtı kullanıldığında, yıllık yakıt tüketim maliyetinin \%54 oranında, kömür yakıt yerine doğalgaz yakıtı kullanılması durumunda ise yıllık yakıt tüketim maliyetinin \%46 oranında azaldığı tespit edilmiştir. Karbondioksit emisyonu açısından, fueloil yakıt yerine doğalgaz yakıtı kullanıldığında $\mathrm{CO}_{2}$ emisyon miktarının \%37 oranında ve kömür yakıt yerine doğalgaz yakıtı kullanılması durumunda ise $\mathrm{CO}_{2}$ emisyon miktarının \%61 oranında azaldığı tespit edilmiştir. Teorik hesaplamalar sonucunda mevcut yakıtlar içerisinde, çevreye en zararlı yakıtın kömür, en çevre dostu yakıtın ise doğalgaz olduğu tespit edilmiştir.

- Hali hazırda kullanılan binanın (II durumu) 1sıtma sezonları için verilen bilgilerin kullanılmasıyla yakıtların tüketimi sonucu oluşan maliyetler incelendiğinde; yakıtların gerçek maliyetlerin teorik maliyetlerinden daha fazla olduğu, bu fazlalık fueloil yakıtında $\% 25$, doğalgaz yakıtında ise $\% 21$ 'lik bir artışı gösterdiği belirlenmiştir. Hem teorik hem de gerçek yakıt tüketimi maliyetlerde en düşük değer doğalgaz yakıtında meydana geldiği görülmüştür. İlgili binada fueloil yakıtı yerine doğalgaz yakıtının kullanılması durumunda, yakıt tüketim maliyetinin teorik $\% 46$, gerçek $\% 44$ oranında azaldığı tespit edilmiştir. Yakıt tüketimi bakımından en ekonomik, en verimli yakıtın doğalgaz yakıtı olduğu görülmüştür. Aynı durumdaki binanın 1sıtma sezonları süresince verilen yakıtların tüketimi sonucu oluşan $\mathrm{CO}_{2}$ emisyonları incelendiğinde; gerçek emisyon değerlerinin teorik değerlerden daha fazla olduğu, teorik ve gerçek en düşük $\mathrm{CO}_{2}$ emisyonunun doğalgaz yakıtında gerçekleştiği belirlenmiştir. Binada fueloil yakıtı yerine doğalgaz yakıtının kullanılması durumunda, $\mathrm{CO}_{2}$ emisyonu miktarının teorik $\% 63$, gerçek $\% 61$ oranında düştüğü tespit edilmiştir. Doğalgaz yakıtının kullanılan yakıtlar içerisinde çevre ve insan sağlı̆̆ açısından en uygun yakıtın olduğu tespit edilmiştir.

- Yukarıda belirtilen değerlendirmeler ışı̆̆ında Bitlis İli için merkezi 1sıtma sitemlerinde mevcut yakıtlar içerisinde en ekonomik, en tasarruflu ve en çevreci yakıt türünün doğalgaz olduğu sonucuna varılmıştır.

\section{Teşekkür}

Çalışma kapsamında verdikleri bilgiler için Bitlis Eren Üniversitesi Yapı İşlemleri ve Teknik Daire Başkanlığı ile İdari ve Mali İşler Daire Başkanlığı personellerine teşekkür ederiz.

\section{Yazarların Katkısı}

Bu çalışma, Dr. Öğr. Üyesi Faruk ORAL danışmanlığında Ali ELHUVEYDİ tarafindan hazırlanan yüksek lisans tez çalışmasından üretilmiştir.

\section{Çıkar Çatışması Beyanı}

Yazarlar arasında herhangi bir çıkar çatışması bulunmamaktadır. 


\section{Araştırma ve Yayın Etiği Beyanı}

Yapılan çalışmada araştırma ve yayın etiğine uyulmuştur.

\section{Kaynaklar}

[1] Çomaklı K., Çakır U., Efe Ş. 2011. Farklı Bina Tipleri ve Yakıtlar İçin Merkezi Isıtma Sistemlerinin Maliyet Analizi. 10.Ulusal Tesisat Mühendisliği Kongresi, 13-16 Nisan, İzmir.

[2] Rüşen S.E., Topçu M.A., Celep G.K., Çeltek S.A., Rüşen A. 2018. Üniversite Kampüs Binalar1 İçin Enerji Etüdü: Örnek Çalışma. Çukurova Üniversitesi Mühendislik Mimarlık Fakültesi Dergisi, 33 (2): 83-92.

[3] Doğan H., Yılankırkan N. 2015. Türkiye'nin Enerji Verimliliği Potansiyeli ve Projeksiyonu. Gazi Üniversitesi Fen Bilimleri Enstitüsü Dergisi, 3 (1): 375-383.

[4] Gürel A.E., Daşdemir A. 2011. Türkiye'nin Dört Farklı İklim Bölgesinde Isıtma ve Soğutma Yükleri İçin Optimum Yalıtım Kalınlıklarının Belirlenmesi. Erciyes Üniversitesi Fen Bilimleri Enstitüsü Dergisi, 27 (4): 346-352.

[5] Yılmaz A. 2012. Apartmanların Dış Kabuğuna Uygulanan Isı Yalıtımının Bina Enerji Performansına Etkisi (Konya ve Erzincan Örneği). Yüksek Lisans Tezi, Selçuk Üniversitesi, Fen Bilimleri Enstitüsü, Konya.

[6] Oğuz Y., Kırmacı V. 2015. Bartın İlinde Kullanılan Isıtma Sistemlerinin Ekonomik ve Çevresel Etkilerinin İncelenmesi. Bartın Üniversitesi Mühendislik ve Teknoloji Bilimleri Dergisi, 3 (1): 410.

[7] Kaya M., Furat İ., Çomaklı Ö. 2016. Economic Analysis of Effect on Energy Saving of Thermal Insulation at Buildings in Erzincan Provice. Journal of Thermal Science and Technology, 36 (1): 47-55.

[8] Canbolat A.S., Kaynaklı Ö., Türkan B., Etemoğlu A.B., Yamankaradeniz R. 2018. Farklı İklimsel Bölgelerde Bulunan Binalarda Yapılan Yalıtımın Termal ve Ekonomik Analizi. Engineering Sciences, 13 (2): 85-95.

[9] Manioğlu G. 2015. Isıtma Sisteminin İşletme Biçiminin Bina Kabuğuna Bağlı Olarak Isıtma Enerjisi Ekonomisi Açısından Belirlenmesi. Tesisat Mühendisliği Dergisi, 85: 7-16.

[10] Karakoç T.H. 2011. KTH Kalorifer Tesisatı Hesab1 Verimli Sistemler. Anadolu Üniversitesi, Nisan Kitabevi Ders Kitapları Yayınları, Eskişehir.

[11] TS 825, Binalarda Is1 Yalıtım Kuralları, Türk Standartları Enstitüsü, Aralık 2013.

[12] https://www.hakedis.org/endeksler/epdk-akaryakit-bayi-satis-fiyatlari (Erişim tarihi: 25.02.2020).

[13] 2019-2020 Y11 için kömür birim fiyatı. https://www.enerjiportali.com/komur-fiyatlari-2/ (Erişim tarihi:15.5.2019).

[14] https://dogugaz.com.tr/iletisim.php (Erişim tarihi: 05.02.2020). 